\title{
Sport: An Ethos Based on Values and Servant Leadership
}

\author{
Joy T. DeSensi \\ University of Tennessee
}

\begin{abstract}
Concluding remarks for this special issue of the Journal of Intercollegiate Sport on Ethical Leadership in Intercollegiate Sport note the numerous breaches of ethical and moral behavior in a physical and personal space that have the potential to develop character, moral development, self-efficacy, respect, and personal honorable significance. While it is easier to speak from higher ground, regarding ethical behavior in intercollegiate athletics, the implementation of such is a problem held by many of those associated with this level of sport. The challenges are many in this area and the actions are met with resistance when massification and commodification are considered regarding sport in the educational setting. The direction of this paper is to educate those who are or will be in roles affiliated with intercollegiate sport by developing an ethical awareness of their moral values and creating a legacy of action based on servant leadership.
\end{abstract}

In the papers published in this special issue, authors have articulately covered some of the very real ethical and moral issues intercollegiate athletics programs are facing (Burton \& Welty Peachey, 2014; Roby, 2014; Sagas \& Wigley, 2014; Staurowsky, 2014). These issues cover both the breach of ethical considerations as well as the subsequent moral transgressions which have affected the essence of competitive games. Challenging issues such as human rights violations, cheating, lack of corporate social and personal responsibility, and respect are just a few of the concerns our intercollegiate sport leaders and participants face daily. The basis of these emanates from the character of each individual involved with intercollegiate sport; that is, integrity, justice, truth, fairness, respect, and beneficence. Some may title these points as just pure "humanness", or as Parry (2010) refers to as the role and responsibilities of players. Westerners tend to extol the ability of sport as a character building space while on the contrary, it may serve as a place of consternation, repugnant actions, and hate. Taking the philosophical stand that intercollegiate sports are neither inherently good nor bad, but rather have the potential to be both, is incumbent upon the intent of the sport itself, the manner in which it manifests itself, and the leadership which guides it.

DeSensi is with the Department of Kinesiology, Recreation and Sport Studies, and Associate Dean, Graduate School, The University of Tennessee, Knoxville, TN. Address author correspondence to Joy DeSensi at desensi@utk.edu. 
The mission statement of the educational institution and how intercollegiate athletics fits into this overall mission requires serious consideration. The current status of intercollegiate athletics has experienced a transformation in the role it appears to have played throughout history to the present time. The educational value of developing the body, mind, and spirit of students, has transformed into campus, state, regional, national, and global entertainment, money making ventures, and spectacles which have impacted not only the recruitment of college athletes, but the recruitment of the general student body as well. Serving as a primary public relations tool for colleges and universities, intercollegiate athletics has developed into a monumental enterprise for both the student-athletes and colleges/universities. Massification and commodification are alive and well in the "business" of intercollegiate sport, not apart from that of the professional level, except for the fact that student-athlete is a dual role and often disguised as a way for those in charge to flourish. Every athlete, however, does not flourish and may never receive a degree, particularly in NCAA Division I athletics programs.

From a functionalist perspective, society and capitalism have played a significant part in the transition of intercollegiate athletics. Considering the issues the previous authors have discussed in addition to the concepts expressed here, it is no wonder that there is a need for further reflection on the role ethics and morality play in intercollegiate athletics.

What is offered herein is an examination of the ethos of sport, developing a values approach, and servant leadership as a way to move to the future of having ethical responsibility and moral action go hand in hand in intercollegiate sport. It is not the intention to predict the future, but rather to explore what is possible to help intercollegiate sport leaders make informed decisions by accepting responsibility based on sound ethical and moral considerations.

\section{The Ethos of Sport}

The cultivation of an ethos or a moral atmosphere in intercollegiate sport, as in any other realm of life, requires a good moral education (Jones, 2005). Exploring the moral atmosphere of intercollegiate sport may sound like a contradiction of terms, but what is evident is the tremendous need in light of the examples of misconduct presented in this special issue. To cultivate a moral ethos in sport, teaching and learning of the correct execution and intention of specific skills and rules must be inculcated and rewarded from the onset. Various types of rules serve as measures of control for restricting the behaviors of players, coaches, and spectators. Legislated by sport governing bodies, constitutive rules explain how the game should be played and serve to equalize the competition by indicating, for example, details of the playing area, numbers and positions of players on a team, and how much physical contact is permitted, depending on the specific game. Breaking such rules results in some sort of punishment or penalty that would give an advantage to the other team (e.g., a foul or loss of yardage). Proscriptive rules are designed to eliminate violence and serious injury by indicating that the body and equipment may not to be used as a weapon against players (DeSensi \& Rosenberg, 2010). The rules of sportsmanship require following the letter and spirit of the rules. Honor and respect are emphasized within rules of sportsmanship. Fair play implies having self-respect and respect and cooperative behavior toward all involved in the competitive sport environment (Butler, 2000). 
What is obvious in the papers presented in this special issue is the range of ethical and moral actions which disregard in some way, all of the rules noted previously (Sagas \& Wigley, 2014; Staurowsky, 2014). In order for a good contest to occur, Fraleigh (1984) remarked:

....although it is clearly possible to break the rules, to do so alters the conditions of the contest, so that a range of abilities not specified by the rules comes into play. A good contest will maintain the framework, that secures the integrity of the contest, and this requires rules adherence and fair play (p. 41).

In spite of this position, there are other points to consider. Fraleigh goes on to note that at the same time, right and wrong actions exist in games which are enforced by authority, but there may be different ways to interpret these. As a result, participants ". . . learn how to follow explicit rules, how to bend them and evade them, and how to operate within a system of penalties and consequences, both official and unofficial" (p. 41). This returns us then to the place in competitive sport where ethical practice becomes truly important. There are definite ethical responsibilities placed upon sport participants, as stated in the rules and based on the concepts of respect and justice. If the rules are broken, especially in an intentional way, the ethos of the game is tainted. In reference to Fraleigh's points, Parry (2010) reminds us that "the rules are interpreted and applied from within a context of the more broadly understood values of a community which supports the practice" (p. 319). The ethos of sport as a moral atmosphere is not, however, a fixed aspect, but rather, one in which the inherent values of competitive sport are constantly tested by athletes, coaches, fans, media, and others stakeholders who impact sport.

Parry (2010) rightly refers to sport as a laboratory "for value experiments" ( $p$. 320 ) in which athletes practice responding to ethical challenges in pressure situation, but this is only one way to envision sport. The ethos is often challenged when participants, investors, and patrons act against the positive values of sport, thus changing the ethos to a space of materialistic gain not concerned with the welfare of all involved. It can be said that the ethos of any situation has the potential of turning away from inherent values. The question related to sport then becomes, Whose Ethos and What Ethos? This question is most appropriately related to the papers contained in this special issue which outline the current indiscretions of intercollegiate sport.

\section{Character Education and Values}

Kretchmar (1994) makes clear the point that many associated with sport have developed a moral insensitivity or moral callouses from a lack of caring. He points out that moral sensitivity is when we can identify moral dilemmas and actually exhibit a concern about them. Moral callousness involves less care, concern, and moral sensitivity. Symptoms of moral callousness according to Kretchmar involve: (a) frequent appeals to the fact that "everyone is doing it" (i.e., cheating), therefore, how could it be wrong?; b) the inability to distinguish between what is part of the game and what is not (If there are no penalties in the rulebook for behavior $\mathrm{x}$, behavior $x$ must be part of the game.); c) difficulty in telling morally sound strategy from win-at-all-costs trickery (Some blatant rule breaking is now referred to by the 
media as "shred strategy"; and d) a sense that if one is not caught, nothing wrong occurred (Whatever works is right.)

Character education certainly needs to be considered in the ethos of intercollegiate sport in its current form. When considering Kretchmar's (1994) examples of moral callousness, such actions can certainly be traced back to lack of character development and values. Those who extol the positive character building aspects of sport may often be perplexed when it comes to actually defining the term "character". If "character actually does count", for what does it count? Its meaning goes far deeper than the explanation that character is what we do when no one is watching. Developing personal character involving the notions of integrity, responsibility, justice, fairness, equality, and respect is difficult at best in sport, which in so many ways seems to act contrary to these concepts. As sport participants, reflecting upon and practicing good character are paramount to developing virtuous behavior and a true ethos of sport.

Character does not just emerge from individuals without learning about underlying values individuals develop and how these influence our character. Developing character is certainly about understanding what an individual values and making conscious choices regarding what values to act upon.

Moral values encompass those points noted in character education; that is, integrity, responsibility, respect, justice, fairness, equality, and beneficence, for example. Each of these holds a prominent place in the ethos of sport. Nonmoral values are those not characterized by moral virtues. These may include materialistic items such as wealth, success, winning, and a myriad of material items. Social values such as hard work, perseverance, and loyalty, for example, depending on how instilled in individuals, also contribute to the ethos of sport. The point of loyalty has been challenged in that it is possible that one could be loyal to an immoral cause or immoral coach. Core values are those moral values we choose to always act upon and hold a significant place in a sportsperson's development of character and contribution to the realm of competitive sport. Core values have the potential to seal the moral commitment to one's good actions in sport and ultimately impact the ethos (Lumpkin, Stoll, \& Beller, 1999).

The opportunity for reflection by athletes on such values usually does not occur unless a coach educated in this knowledge, aware of his or her own values, and committed to the moral advancement of intercollegiate athletics makes this happen. Often, the issue arises as to the belatedness of attempting to educate athletes, coaches, and sport managers to consider the ethical perspectives regarding the ethos, character building, and moral development of intercollegiate sport. Given the increased degradation of sport, if now is not the time, when is? Because of the complexity and significant growth of intercollegiate sport, there exists an abundance of competing values. "Sport managers must learn to identify and evaluate values related to the bureaucratic and business aspect of sport. They must then seek to evoke positive change so ethical behavior and practices are championed. ... (DeSensi \& Rosenberg, 2010, p. 16).

\section{Servant Leadership}

It is with much respect for the editors of this special issue, that I place their article "The Call for Servant Leadership in Intercollegiate Athletics" published in Quest in 2013 at the forefront of what I consider to be a supreme example of the points 
attempted to be made in this paper. Servant leadership, as noted by Burton and Welty Peachey (2013), is an “ . . ideal of service in the relationship between leader and follower. ... . [and] is a people-centered approach to leadership that includes an ethical component" (p. 354). Focusing on the relationship of the leader and follower, servant leadership allows the leader to consider the needs of followers and to serve followers initially, not to lead first. Current leadership styles exhibited in intercollegiate athletics tend to be ones in which the coach is constantly leading, manipulating, and motivating players in specific ways which they believe will lead to winning. Concern for the needs and aspirations of athletes, followers in this case, does not seem to be at the forefront of coaching/leading responsibilities, nor is nurturing a part of the leader's intent. Engaging people as whole individuals with heart, mind, and spirit allows for a deeper consideration of followers. Burton and Welty Peachey indicate there is a better chance of organizational objectives being met as well. There is much to be said regarding the potential of leading to the development of followers and employees' values, character, and the overall ethos of sport. With the emphasis on the welfare of the followers (i.e., athletes and employees), building trust, integrity, authenticity, and inclusion, servant leadership is congruent with the moral values discussed previously and helps bring athletes to understand the importance of developing values which in turn, attribute to character.

The characteristics of servant leadership offered by van Dierendonck (2011) are inextricably intertwined with a moral imperative that must be addressed in intercollegiate athletics and related to the concepts of ethos, character, and values. These include (a) empowering and developing people, (b) humility, (c) authenticity, (d) interpersonal acceptance, (e) providing direction, and (f) stewardship. Empowering and developing individuals refers to instilling self-confidence in followers, empowering self-directed decision making and acknowledging the intrinsic value of each individual. Leaders demonstrating humility place followers first, offer support, assist with followers' performance, and listen to their contributions. Being true to oneself is an example of authenticity. Sharing thoughts, keeping promises, and knowing who the individual is as a person, are paramount. Interpersonal acceptance refers to creating a safe environment for followers. Compassion, forgiveness, and empathy are crucial so that followers may work through mistakes. What is brought to light with the characteristic of compassion is Coach Rice at Rutgers University who demeaned, threatened, and physically abused players who made mistakes in practices. Every servant leader provides direction, informing followers of their responsibilities and accountability. Personalizing directions based on the needs and abilities of followers is essential and particularly relevant to the specific positions athletes play in various sports. Stewardship is obviously needed since the servant leader serves as a role model and caretaker who considers the student-athletes' welfare most of all. Social responsibility enters into this characteristic of the servant leader as she/he is morally and socially responsible for all others.

\section{Conclusion}

With the ever increasing number of moral dilemmas imbedded in the culture of intercollegiate athletics, it is paramount that everyone associated with the education of future sport managers practice social and moral responsibility, including coaches, trainers, administrators, media personnel, and the National Collegiate 
Athletic Association. Individual ethical conduct must demonstrate responsibility, accountability, and sound ethical decision-making on the part of all involved in this venture.

This special issue of the Journal of Intercollegiate Athletics addresses the most important aspects of intercollegiate athletics. Its timely recounting of ethical dilemmas (Burton \& Welty Peachey, 2014; Roby, 2014) the commentary on actions (Staurowsky, 2014), and the scholarship regarding the call for ethical reform (Sagas \& Wigley, 2014), should not fall on deaf ears.

The quote from Burton and Welty Peachey (2013) that follows emphasizes the ethos, character, values, and leadership style that will certainly make a major contribution to the ethical development of intercollegiate athletics:

We propose that athletic directors demonstrating servant leadership will provide the leadership necessary to support the development of student- athletes, cultivate an ethical environment that best supports this development and inspire the call to service for employees within their athletic departments (p. 354).

The journey to moral excellence in intercollegiate sport is paramount for the sake of the individuals it directly serves, the student-athletes.

\section{References}

Burton, L., \& Welty Peachey, J. (2013). The call for servant leadership in intercollegiate athletics. Quest, 65, 354-371. doi:10.1080/00336297.2013.791870

Burton, L., \& Welty Peachey, J. (2014). Ethical leadership in intercollegiate sport: Challenges, opportunities, and future directions. Journal of Intercollegiate Sport, 7, 1-10.

Butler, L.F. (2000). Fair play: Respect for all. Journal of Physical Education, Recreation \& Dance, 71, 32-35. doi:10.1080/07303084.2000.10606000

DeSensi, J.T., \& Rosenberg, D. (2010). Ethics and morality in sport management. Morgantown, WV: Fitness Information Technology.

Fraleigh, W. (1984). Right actions in sport. Champaign, IL: Human Kinetics.

Jones, C. (2005). Character, virtue and physical education. European Physical Education Review, 11(2), 139-151. doi:10.1177/1356336X05052893

Kretchmar, R.S. (1994). Practical philosophy of sport. Champaign, IL: Human Kinetics.

Lumpkin, A., Stoll, S.K., \& Beller, J.M. (1999). Sport ethics: Applications for fair play (2nd ed.). Boston: McGraw-Hill.

Parry, J. (2010). Sport, ethos and education. In M. McNamee (Ed.), Ethics in sport: A reader. NY: Routledge.

Roby, P. (2014). Ethical leadership in college athletics. Journal of Intercollegiate Sport, 7, 35-39.

Sagas, M., \& Wigley, B.T. (2014). Grey area ethical leadership in the NCAA: The ethics of doing the wrong things right. Journal of Intercollegiate Sport, 7, 40-57.

Staurowsky, E.J. (2014). College athletes' rights in the age of the super conference: The case of the All Players United campaign. Journal of Intercollegiate Sport, 7, 11-34.

van Dierendonck, D. (2011). Servant leadership: A review and syntheses. Journal of Management, 27, 1228-1261. doi:10.1177/0149206310380462 